\title{
A Narrative Review: In-vitro Methods for Assessing Bio-Accessibility/ Bioavailability of Iron in Plant-Based Foods
}

\author{
N. Sulaiman ${ }^{1 *}$, D. I. Givens ${ }^{1}$ and S. Anitha ${ }^{2}$ \\ 1 Institute for Food Nutrition and Health, School of Agriculture Policy and Development, University of Reading, Reading, \\ United Kingdom, ${ }^{2}$ International Crops Research Institute for the Semi-Arid Tropics Patancheru, Hyderabad, India
}

In-vitro measurement has the advantage of rapid and convenient method of screening the iron bioavailability within the range of plant-based foods. It is important to do preliminary screening as it provides information which will be useful to identify promising plant sources of iron before moving to human trials. A review on in-vitro methods of bio-accessibility and bioavailability of iron in plant-based foods including fruits, vegetables, cereals and legumes is entailed here. The review will focus on in-vitro methods of iron bioavailability in plant-based foods and the effects of inhibitors and processing on the iron bioavailability. The variation of the methods and updates on a recent INFOGEST method used to measure the bioavailability of iron in plant-based foods will also be discussed.

Keywords: in-vitro, iron, bioavailability, bio-accessibility, INFOGEST

\section{INTRODUCTION}

In the recent years, a successive increase in encouraging people to consume more plant-based foods has been observed due to their benefit to health as well as being sustainable. In parts of the world especially in low-and middle-income countries (LMIC), plant-based foods contribute to a high proportion of the dietary intake. In these countries, plant-based foods are the main source of macro-and micronutrients including iron. However, inadequate consumption of ironrich plant-based food, consumption of large quantities of refined food and inadequately fortified food eventually contribute to dietary iron deficiency and poor bio-accessibility/bioavailability of iron to play its functional role in the body. The amount of iron in vegetables, fruits, cereals and legumes range between $0.3-13.9,0.2-2.8,1.5-7.6$ and $6.2-15.7 \mathrm{mg} / 100 \mathrm{~g}$ respectively (Rousseau et al., 2020). One of the main concerns associated with having plant-based foods as the main source of iron, particularly in LMIC countries where intake of red meat is low, is its limited bioaccessibility/bioavailability from plant-based foods which contributes to iron deficiency problems (Platel and Srinivasan, 2016). Bio-accessibility is the amount of ingested nutrient that is released from the food matrix and potentially available for absorption and physiological function and bioavailability is defined as the amount of ingested nutrient that is absorbed and available for physiological functions (Etcheverry et al., 2012). Both are dependent on digestion and release from the food matrix, but bioavailability is also dependent on absorption by intestinal cells and transport to body cells. In this review, bioavailability will be used to explain both terms despite the difference in the meaning as recognized by most of the studies referenced in here. Moreover, in order for a nutrient to be bioavailable it has to be bio-accessible. 
Bioavailability of iron is strongly influenced by the balance between iron inhibitors and enhancers that act as controlling factors for iron absorption. Anti-nutrients such as phytic acid, tannin, calcium and dietary fiber are the main inhibitors of iron absorption. Plant cell walls can act as a physical barrier which reduces the digestibility of the food matrix which can also reduce the mineral bioavailability (Rousseau et al., 2020). Even though many plant-based foods are rich in iron and other minerals, it is important to acknowledge that the release of these nutrients might be limited due to several factors impacting their absorption and therefore bioavailability.

Iron deficiency is one of the most prevalent forms of malnutrition affecting nearly $30 \%$ of the world's population including $29 \%$ of non-pregnant women, $38 \%$ of pregnant women and $43 \%$ of children worldwide (WHO, 2020). Low iron intake due to diets that are poor in iron and particularly low bioavailable, non-haem iron can contribute to iron deficiency. Iron deficiency is most likely to occur in LMIC countries. Therefore, it is of great importance to investigate the effects of different plant types and processing methods including cooking, on the bioavailability of minerals to ensure that diets can be formulated to ensure that adequate amounts of nutrients are available for absorption. This will also allow further strategies to be implemented to improve the bioavailability of micronutrients from plant-based foods to address issues on mineral deficiencies.

Generally, there are four main in-vitro methods used for measuring iron bioavailability, which are solubility, dialysability, gastrointestinal models and Caco- 2 cell models. Each has its own advantages and disadvantages of the endpoint measurement. It is also important to note the form of the plant-based food whether it is consumed as an individual food or within a meal. This review will focus on the four methods used to measure iron bioavailability in plant-based foods either in raw or cooked form.

The aim of the review is to update information on recent invitro method called INFOGEST (Minekus et al., 2014) along with other commonly used in-vitro solubility, dialysability and Caco2 cell culture methods used as an alternative to human studies. Limitations and recommendation are also discussed.

\section{IRON IN THE DIET}

Iron is an essential micronutrient as it plays an important role in oxygen transport, oxidative metabolism, cellular proliferation and other physiological functions (Nair and Iyengar, 2009). Dietary iron exists in two forms, haem and non-haem iron. Haem iron is only found in animal-based foods such as red meat, poultry and seafood and typically about $40 \%$ of the iron is in the haem form which has good bioavailability. The other $60 \%$ of the iron in animal tissues is in non-haem form. All of the iron in plant-based food is the non-haem form and is less bioavailable (Nair and Iyengar, 2009; Pizarro et al., 2016). According to a review by Rousseau et al. (2020) the absorption of haem iron is facilitated through haem iron specific receptors on the microvilli of the enterocytes where it will split from the porphyrin ring complex once it is absorbed. With non-haem iron, a distinction must be made between iron in ferrous state $\left(\mathrm{Fe}^{2+}\right)$ and the ferric state $\left(\mathrm{Fe}^{3+}\right)$. The important step impacting iron bioavailability is the reduction of ferric to ferrous by the action of gastric acid and ferric reductases in the intestinal lumen (Ferruzzi et al., 2020). The transporter carries iron in the ferrous state together with the protons across the mucosal membrane. However, most of the non-haem iron that enters the gastrointestinal tract is in the ferric state which is insoluble and has low bioavailability. In the ferric state, the iron must be reduced before it can be absorbed at the enterocyte (Nair and Iyengar, 2009). However, there are dietary components capable of reducing $\mathrm{Fe}^{3+}$ to $\mathrm{Fe}^{2+}$ such as ascorbic acid (Blanco-Rojo and Vaquero, 2019).

A review by Hurrell and Egli (2010), found that the percentage of iron bioavailability in mixed diets is estimated to be in the range of $14-18 \%$ whereas, it is $5-12 \%$ from vegetable diets typical of those in Western countries. This means that, while inadequate intake of iron contributes to the problem of iron deficiency, lower bioavailability of iron from plant-based diets also contributes to this problem. Vegetarians who depend on plant-based diets are more susceptible to iron deficiency due to the lower bioavailability of non-haem iron. According to ICMR-NIN (2020), dietary iron assumed absorbability from plant-based foods varies and is given as $8 \%$ for men, women, lactating women and adolescents, $12 \%$ for pregnant women, $15 \%$ for infants (6-12 months) and 6\% for children. Using these values and assuming the concentration of $15 \mathrm{mg} \mathrm{Fe} / 100 \mathrm{~g}$ of plant-based foods, $100 \mathrm{~g}$ would provide $0.9,1.2,1.8$ and 2.3 $\mathrm{mg} / \mathrm{d}$ of absorbable iron for children, men (also for women, lactating women and adolescents), pregnant women and infants respectively. Accordingly, this would only meet the ICMR-NIN (2020) net physiological estimated average requirement [i.e., EAR * (absorbability\%/100) of iron for men $(0.88 \mathrm{mg} / \mathrm{d})$, nonpregnant and non-lactating women $(1.20 \mathrm{mg} / \mathrm{d})$, children $(0.36-$ $0.60 \mathrm{mg} / \mathrm{d})$, and young adolescents $(0.96 \mathrm{mg} / \mathrm{d})]$. There are strategies aimed at increasing the iron concentration in major crops such as millets and beans by bio-fortification, however this does not directly translate into an increase in absorbed iron. Moreover, it is important to understand the bioavailability of iron in such new initiatives like bio-fortification, before suggesting for nutrition interventions, dietary plans or policy changes. It is also necessary to understand the effects of enhancers or new enhanced crops by screening their iron bioavailability. To generate evidence-based science on iron bioavailability, invitro methods are considered simple, cost effective (compared to human efficacy studies) and useful screening tools as a first step to evaluate the bioavailability.

\section{BARRIERS/FACTORS IMPACTING IRON BIOAVAILABILITY FROM PLANT-BASED FOODS}

Antinutrients are abundant in plant-based foods and their main role is to act as chemical defense mechanism against pathogens and often interfere with the digestion and absorption of micronutrients. Phytic acid is one of the major inhibitors of iron bioavailability as it forms a complex with iron and is often present in high concentrations (Glahn et al., 2016). It is a 
principal storage form of phosphate found in plants, particularly in cereals and legumes. The high negative charge present on phytic acid at the small intestinal $\mathrm{pH}$ of 6 to 7 facilitates the chelation with iron resulting in insoluble complexes which reduce iron bioavailability (Ferruzzi et al., 2020).

Phenolic compounds such as tannins are also known to impact iron bioavailability. In the case of pearl millet, the iron bioavailability was not only affected by phytate but also by tannins (Lestienne et al., 2005a). Similarly, dietary fiber also contributes to reduced bioavailability as it has the ability to bind minerals.

There is also evidence suggesting that physical barriers such as the cell wall from beans' cotyledons and intracellular matrix contribute a significant barrier to iron absorption (Mamiro et al., 2001; Glahn et al., 2016). Therefore, the in-vitro studies could provide an insight to the effects of processing on the bioavailability of iron from various of plant-based sources and the bioavailability of different grain fractions.

A recent review by Glahn and Noh (2021) discussed about the need to redefine the current approach to iron bio-fortification particularly in common beans. According to the author, the current bio-fortification program may not be effective due to lack of data from in-vitro methods, animal studies and other analytical techniques to facilitate strategic human studies. The alternative approach to improve the nutritional quality of iron from beans is to understand factors and traits that affect iron bioavailability. The factors include disruption of the cotyledon cell wall in order to release intracellular iron, reduction of phytic acid by using endogenous phytase or soaking prior to consumption, the influence of other components in the diet or within a meal and traits such as seed polyphenolic that enhance iron bioavailability.

Despite the barriers, iron bioavailability can be improved by the addition of enhancers such as ascorbic acid. Many in-vitro studies showed a positive enhancement on the bioavailability of iron using ascorbic acid when added to lentils, white beans and carioca beans, yellow beans and black beans (Glahn et al., 2016). In this study, the ascorbic acid was added to the digests at the start of the gastric phase at a concentration of $10 \mu \mathrm{mol} / \mathrm{L}$. The addition of ascorbic acid enhanced the iron bioavailability in lentil, white bean, carioca bean and pressure-cooked black bean sample. This proves that in-vitro measurements are an important tool to study the effects of enhancers or fortifications to improve the bioavailability of iron in plant-based foods.

Furthermore, the bioavailability of iron can be influenced by processing methods such as cooking, which can increase the bioavailability of iron as it may reduce the content of antinutrients such as phytate and when heat is introduced resulting in softening of the food matrix and releasing iron that is bound to protein (Hemalatha et al., 2007a).

\section{In-vitro METHODS OF INVESTIGATING BIOAVAILABILITY OF IRON}

As mentioned above, in-vitro methods are considered as an appealing alternative to human and animal in-vivo studies. They are used as a tool to measure the iron bioavailability in various samples because of the simple, low cost and rapid technique that can be replicated inter-and intra-laboratory. Moreover, human studies present higher variability due to potentially large variability between subjects' iron status. In-vitro methods are also useful to assess the effects of processing, bio-fortification, and enhancers on iron bioavailability. Previous studies have used various types of in-vitro methods for cereals, legumes and fruits and vegetables.

There are four widely used in-vitro methods for accessing bioavailability of iron and the main principal of these methods is to simulate the upper gastrointestinal tract digestion. Iron absorption mainly occurs in the small intestine, hence the endpoint for measuring the iron bioavailability is in the equivalent of upper small intestine (Bohn et al., 2018).

\section{Iron Solubility}

The first proposed method for measuring the bioavailability of iron was by Miller et al. (1981) using the principal methods of solubility and dialysability and was later modified by Kapsokefalou and Miller (1991). These models are used to simulate the gastric and intestinal conditions with controlled temperature, agitation, $\mathrm{pH}$, enzyme and chemical composition. The gastric phase is performed with $\mathrm{HCl}$ or $\mathrm{HCl}$-pepsin under fixed $\mathrm{pH}$ and temperature conditions. The food is incubated at a pH range of 1 to 3 at $37^{\circ} \mathrm{C}$ for 1 to $3 \mathrm{~h}$. This is followed by an intestinal phase with the addition of pancreatin and bile at neutral $\mathrm{pH}$ for between $30 \mathrm{~min}$ and $2 \mathrm{~h}$. The solubility method requires centrifugation to separate the supernatant and pellet prior to the measurement of iron in the soluble fraction. The range of $\mathrm{pH}$ and time used for incubation directly affect the bioavailability of the iron.

As outlined previously, a high iron content is not always related to high iron bioavailability. A study using in-vitro solubility has been reported by Sahuquillo et al. (2003) on iron bioavailability from chickpeas, white beans and lentils using $10 \mathrm{~g}$ and $20 \mathrm{~g}$ of flour of each legume. This study showed that lentils had the highest total iron content compared to white beans and chickpeas but the lowest iron bioavailability. The authors also mentioned that the comparison of the values with those reported in the literature is difficult due to differences in the methods used. As shown in Table $\mathbf{1}$ there were differences in $\mathrm{pH}$, time of incubation, centrifugation force and other additional modifications amongst studies which are important factors for this method.

As mentioned previously, phytates and fibers are inherent factors that reduce iron bioavailability. A study by Lestienne et al. (2005b) explored the effects of these inhibitors on iron bioavailability in pearl millet flour using an in-vitro solubility method. The flours were treated with endogenous and exogenous phytase to reduce the phytate content. The iron bioavailability of the different fractions of whole pearl millet grain with low and high fiber and tannin contents were also investigated (Lestienne et al., 2005a). The $\mathrm{pH}$ used in gastric phase was 2 for $1 \mathrm{~h}$ and the intestinal phase was $\mathrm{pH} 7$ for $2 \mathrm{~h}$. A study by Luo et al. (2010) investigated the effects of phytate degradation in faba bean flour and Luo et al. (2013) on the effects of germination and cooking on faba bean, azuki bean and mung bean sprouts on the iron 
TABLE 1 | Iron bioavailability studies using in-vitro solubility methods.

\begin{tabular}{|c|c|c|c|c|c|c|}
\hline \multirow{2}{*}{ Type of study/foods } & \multicolumn{3}{|c|}{ Conditions ( $\mathrm{pH}$, incubation time, centrifugation, buffer) } & \multirow{2}{*}{ Iron quantification } & \multirow{2}{*}{ Findings } & \multirow{2}{*}{ References } \\
\hline & Oral phase & Gastric phase & Intestinal phase & & & \\
\hline $\begin{array}{l}\text { Estimating the bio-accessibilities of } \\
\text { iron form white beans, lentils and } \\
\text { chickpeas with the influence of the } \\
\text { sample size }\end{array}$ & - & $\begin{array}{l}\text { Simple assay with } 10 \mathrm{~g} \text { of } \\
\text { ground legumes used } \\
\text { Double assay } 20 \mathrm{~g} \text { of } \\
\text { ground legumes used } \\
\text { Pesin, } \mathrm{HCl}, \mathrm{pH} 2,37^{\circ} \mathrm{C} \text {, } \\
2 \mathrm{~h}\end{array}$ & $\begin{array}{l}1 \mathrm{M} \mathrm{NaHCO}_{3} \text { to raise the } \\
\mathrm{pH} \text { to } 5, \text { pancreatin-bile, } \\
37^{\circ} \mathrm{C} \text { for } 2 \mathrm{~h} \\
\text { Before centrifugation } \\
(3,200 \mathrm{rpm} 20 \text { min at } \\
20^{\circ} \mathrm{C} \text {, pH was adjusted to } \\
7.2 \text { using } 0.5 \mathrm{M} \mathrm{NaOH}\end{array}$ & $\begin{array}{l}\text { Flame absorption } \\
\text { spectroscopy } \\
\text { (FAAS) }\end{array}$ & $\begin{array}{l}\text { Bioavailability }(\mu \mathrm{g} / \mathrm{g}) \\
\text { White beans } \\
\text { Simple assay } 34.4 \\
\text { Double assay } 34.5 \\
\text { Chickpea } \\
\text { Simple assay } 28.9 \\
\text { Double assay } 28.1 \\
\text { Lentils } \\
\text { Simple assay } 10.7 \\
\text { Double assay } 15.6\end{array}$ & $\begin{array}{l}\text { Sahuquillo et al. } \\
\text { (2003) }\end{array}$ \\
\hline $\begin{array}{l}\text { Effects of phytase treatment on the } \\
\text { iron bioavailability from the whole } \\
\text { pearl millet flours }\end{array}$ & $\begin{array}{l}\text { About } 2 \mathrm{~g} \text { of dry sample } \\
\text { was precisely weighed in } \\
\text { an Erlenmeyer and } \\
\text { suspended in } 20 \mathrm{ml} \text { of } \\
\text { distilled water. }\end{array}$ & $\begin{array}{l}\text { After } 10 \text { min of } \\
\text { conditioning in a shaking } \\
\text { water bath at } 37^{\circ} \mathrm{C}, \mathrm{pH} \\
\text { was adjusted to } 2.0 \text { with } \\
1 \mathrm{M} \mathrm{HCl} \text { solution under } \\
\text { magnetic stirring. Next, } \\
1.0 \mathrm{ml} \text { of the pepsin } \\
\text { solution was added, and } \\
\text { the mixture was incubated } \\
\text { for } 1 \mathrm{~h} \text {. The pH was then } \\
\text { increased to about } 4.0 \\
\text { with } 0.15 \mathrm{mM} \text { PIPES }\end{array}$ & $\begin{array}{l}5.0 \mathrm{ml} \text { of the } \\
\text { pancreatin-bile, and } \mathrm{pH} \\
\text { adjusted to } 7.0 \text { with the } \\
\text { PIPES buffer that allows } \\
\text { minimizing pH variation, } \\
2 \mathrm{~h} \text {. The suspension was } \\
\text { then centrifuged at } \\
10,000 \mathrm{~g} \text { for } 30 \text { min at } 4{ }^{\circ} \mathrm{C}\end{array}$ & AAS & $\begin{array}{l}\text { Bioavailability (\%) } \\
\text { Raw: } 9.9 \% \\
\text { Endogenous phytase } \\
(1 \mathrm{~h}): 22.1 \% \\
\text { Endogenous phytase } \\
(3.5 \mathrm{~h}): 24.1 \% \\
\text { Exogenous phytase } \\
(1 \mathrm{~h}): 17.7 \% \\
\text { Exogenous phytase } \\
(3.5 \mathrm{~h}): 21.4 \%\end{array}$ & $\begin{array}{l}\text { Lestienne et al. } \\
\text { (2005a) }\end{array}$ \\
\hline $\begin{array}{l}\text { Assessing the effects of fiber and } \\
\text { phytate degrading enzymes on iron } \\
\text { solubility from pearl millet flour and } \\
\text { grain fractions }\end{array}$ & - & Pepsin, $\mathrm{HCl}, \mathrm{pH} 2,1 \mathrm{~h}$ & $\begin{array}{l}\text { Pancreatin-bile, } \mathrm{pH} 7,2 \mathrm{~h} \\
\text { Centrifuged at } 10,000 \mathrm{~g} \\
\text { for } 30 \text { min at } 4{ }^{\circ} \mathrm{C}\end{array}$ & AAS & $\begin{array}{l}\text { Bioavailability (\%) } \\
\text { Raw } 24.9 \\
\text { Endogenous phytase } \\
(1 \mathrm{~h}) 42.0 \\
\text { Endogenous phytase } \\
(3.5 \mathrm{~h}) 37.6 \\
\text { Exogenous phytase } \\
(1 \mathrm{~h}) 37.6 \\
\text { Exogenous phytase } \\
(3.5 \mathrm{~h}) 34.2 \\
\text { Decorticated fraction } 41.6 \\
\text { Dephytinized decorticated } \\
\text { fraction } 66.2 \\
\text { Bran fraction } 23.8 \\
\text { Dephytinized bran } \\
\text { fraction } 34.9\end{array}$ & $\begin{array}{l}\text { Lestienne et al. } \\
\text { (2005b) }\end{array}$ \\
\hline $\begin{array}{l}\text { Investigating the effects of phytate } \\
\text { degradation in faba bean flour on } \\
\text { iron bioavailability and in different } \\
\text { fractions with or without } \\
\text { dephytinisation }\end{array}$ & $\begin{array}{l}\alpha \text {-amylase solution }(2 \mathrm{ml}) \\
\text { consisting of } 12,500 \text { units } \\
\mathrm{I}^{-1}, 1.5 \mathrm{~g} \mathrm{I}^{-1} \mathrm{NaCl}, 1.5 \mathrm{~g} \\
\mathrm{I}^{-1} \mathrm{~K}_{2} \mathrm{HPO}_{4} \text { and } 0.5 \mathrm{~g} \mathrm{I}^{-1} \\
\mathrm{Na}_{2} \mathrm{CO}_{3}(\mathrm{pH} 7.0), 30 \mathrm{~min}, \\
37^{\circ} \mathrm{C}\end{array}$ & $\begin{array}{l}\text { Pepsin, } \mathrm{HCl}, \mathrm{pH} 4,1 \mathrm{~h} \text { at } \\
37^{\circ} \mathrm{C}\end{array}$ & $\begin{array}{l}\text { Pancreatin-bile, } \mathrm{pH} 6 \text {, } \\
\mathrm{NaHCO}_{3}, 30 \mathrm{~min} \text { at } 37^{\circ} \mathrm{C} \\
\text { Centrifuged at } 5,000 \times \mathrm{g} \\
\text { for } 15 \mathrm{~min} \text { at } 4^{\circ} \mathrm{C} \\
\text { Supernatants were filtered } \\
\text { using } 0.45 \mu \mathrm{m} \text { membrane }\end{array}$ & AAS & $\begin{array}{l}\text { Bioavailability (\%) } \\
\text { Raw } 32.2 \\
\text { Endogenous phytase } \\
\text { (1 h) } 70.8 \\
\text { Endogenous phytase } \\
\text { (3h) } 78.2\end{array}$ & Luo et al. (2010) \\
\hline
\end{tabular}


Effects of soaking and germination on iron bioavailability from three white Sorghum varieties
$(5 \mathrm{~g})$ were suspended in $30 \mathrm{ml}$ distilled water using $\alpha$-amylase solution

$\alpha$-amylase solution $30 \mathrm{~min}, 37^{\circ} \mathrm{C}$
Pepsin, lipase, $\mathrm{pH} 4,5 \mathrm{M}$ $\mathrm{HCl}, 37^{\circ} \mathrm{C}, 1 \mathrm{~h}$

psin, $\mathrm{HCl}, \mathrm{pH} 4,60 \mathrm{~min}$ at $37^{\circ} \mathrm{C}$

in faba bean, azuki bean and mung bean

Effects of processing and addition

of ascorbic acid on the iron bioavailability in finger millet
HCL-pepsin: $0.03 \mathrm{~N} \mathrm{HCl}$,

$37^{\circ} \mathrm{C}, 3 \mathrm{~h}, \mathrm{pH}$ not

mentioned, filtered, acid

digested
Adjusted to $\mathrm{pH} 6.0$ using solid $\mathrm{NaHCO}_{3}$

pancreatin-bile, $37^{\circ} \mathrm{C}$ $30 \mathrm{~min}$, centrifuged at $3,600 \mathrm{~g}$ for $15 \mathrm{~min}$ Supernatant filtered through $0.45 \mathrm{~mm}$

pore filter

Pancreatin-bile, $\mathrm{pH} 6$ $\mathrm{NaHCO}_{3}, 30 \mathrm{~min}$ at $37^{\circ} \mathrm{C}$ Centrifuged at 5,000 $\times 9$ for 15 min at $4^{\circ} \mathrm{C}$

Supernatants were filtered using $0.45 \mu \mathrm{m}$ membrane

Pepsin-pancreatin:

Pancreatin-bile, $\mathrm{HCl}, \mathrm{pH}$ $5,2 \mathrm{~h}$ at $37^{\circ} \mathrm{C}$
Exogenous phytase

(1 h) 69.2

Exogenous phytase

(3h) 72.0

Dehulled fraction 28.1

Dephytinized dehulled

fraction 58.4

Hull 31.2

Dephytinized hull 33.1

Bioavailability

Raw: 8.02-13.6\%

Soaked: $14.62-20.75 \%$

Germinated:

$16.67-20.63 \%$

\section{Bioavailability $(\mathrm{mg} / \mathrm{kg})$}

Faba bean

Raw, soaked, germinated

26, 48 and $60 \mathrm{~h}: 35.2$,

32.1, 32.5, 33.0, 32.6.

Azuki bean

Raw, soaked, germinated

26, 48 and $60 \mathrm{~h}: 46.8$,

42.5, 42.2, 42.4, 42.5

Mung bean

Raw, soaked, germinated

26, 48 and 60 h: 51.2 ,

48.6, 47.5, 47.8, 47.5

Faba bean

Raw, pressure cooking,

microwave: 32.6,

30.4, 31.3

Azuki bean

Raw, pressure cooking,

microwave: 42.5

40.5, 40.8

Mung bean

Raw, pressure cooking,

microwave: 48, 46.5, 46.5

Bioavailability (\%)

Finger millet (HCL-pepsin)

Raw, soaked, germinated

autoclaved and
Mamiro et

Afify et al. (2011)

Luo et al. (2013) 


\begin{tabular}{ll} 
Oral phase & Gastric phase \\
\hline & Pepsin-pancreatin:
\end{tabular}

Intestinal phase

Pepsin, $\mathrm{HCl}, \mathrm{pH}$ not

mentioned, $2 \mathrm{~h}$ at $37^{\circ} \mathrm{C}$

Three quinoa seeds (Chenopodium quinoa, wild), sweet unpolished, sweet polished and bitter polished Effect of cooking, soaking,

germination and fermentation on

iron bioavailability fermented: 5.06, 6.01

29.91, 42.99, 51.98

Finger

millet (Pepsin-pancreatin)

Raw, soaked, germinated

autoclaved and

fermented: 4.49, 5.88,

$10.57,4.40,4.98$

Finger millet + Vitamin C

(Pepsin-pancreatin)

Raw, soaked, germinated,

autoclaved and

fermented: 5.64, 6.81

$31.20,33.43,33.87$

Finger millet +

Mango (Pepsin-

pancreatin)

Raw, soaked, germinated,

autoclaved and

fermented: 50.51, 54.66

$77.19,75.41,78.55$

Bioavailability (\%)

Sweet unpolished quinoa

Raw, cooking, cooking +

soaking, cooking +

fermentation: 6.6, 6.4

21.6, 30.7

Germinated seeds

Cooking, cooking +

fermentation: 19.8, 38.8

Sweet, polished quinoa

Raw, cooking, cooking +

soaking, cooking +

fermentation: 7.8, 7.7,

18.5, 26.9

Germinated seeds

Cooking, cooking +

fermentation: 23.8, 64.0

Bitter polished

Raw, cooking, cooking +

soaking, cooking +

fermentation: 9.6, 10.4,

37.3, 48.3

Germinated seeds

Cooking, cooking +

fermentation: 23.1, 50.7

Bioavailability (\%)

38 varieties of raw and

cooked beans $(3.2$

to $3.4 \%$ )
Valencia et al. 
bioavailability but adapted the in-vitro solubility method of Kiers et al. (2000) which was slightly different than the method used by Lestienne et al. (2005a,b). Instead of simulating the two key stages of gastric and intestinal phase, the method digested the flours with amylase in the oral phase for $30 \mathrm{~min}$. Additionally, the supernatant was subjected to filtration after centrifugation. The relevance of this modification was to investigate three aspects of digestibility notably solubility, degradability and absorbability. The $\mathrm{pH}$ in gastric phase was 4 for $1 \mathrm{~h}$ and $\mathrm{pH} 6$ for $30 \mathrm{~min}$ in intestinal phase. The iron solubility method used by Lestienne et al. $(2005 \mathrm{a}, \mathrm{b})$; Luo et al. $(2010,2013)$ varied in terms of $\mathrm{pH}$, incubation time and centrifugation force used (Table 1).

Ascorbic acid has been shown to enhance the iron bioavailability of finger millet and red kidney beans as demonstrated in a study by Mamiro et al. (2001) that used two approaches based on in-vitro solubility using HCL-pepsin and pepsin-pancreatin extractability. The former approach measured the iron bioavailability after the gastric phase and the latter measures the iron bioavailability at the end of small intestinal phase producing different values of bioavailability. The HCLpepsin gives higher value of bioavailability compared to the pepsin-pancreatin method. This means that at lower $\mathrm{pH}$ in the gastric phase, the iron is more soluble and as the $\mathrm{pH}$ is raised to simulate the intestinal phase, solubility reduces thus lowering the bioavailability. However, it is important to note that most absorption occurs in duodenum so measuring the iron bioavailability at gastric phase may overestimate the value. According to the review by Etcheverry et al. (2012), the iron solubility method can be a good indicator of iron bioavailability as observed by previous studies which assessed the effects of ascorbic acid on bioavailability. This is because ascorbic acid is known to reduce ferric iron which in insoluble, to ferrous iron which is soluble and therefore iron solubility method is a good indicator of measuring iron bioavailability.

The $\mathrm{pH}$ and time of incubation in the gastric and intestinal phases in the study by (Valencia et al., 1999) was $\mathrm{pH} 1.8$ and 90 min incubation time followed by $\mathrm{pH} 5$ for 30 min then $\mathrm{pH} 6$ prior to centrifugation (Table 1). This study adjusted the $\mathrm{pH}$ to 6 due to the high correlation with results from human studies on iron absorption from 20 vegetarian diets. In this study, the effect of different traditional processes including cooking, soaking, germination, and fermentation on the in-vitro bioavailability of iron in quinoa products was observed. As seen in all of these studies, in-vitro solubility had great flexibility and adaptability depending on the aim of the research.

The in-vitro solubility method has also been used to estimate the bioavailability of iron in legume samples. Mamiro et al. (2016) studied 38 different varieties of raw and cooked dry beans and green shelled beans. Diverse variation was observed between different varieties and the green shelled beans showed higher bioavailability compared to dry beans. A study by Sahuquillo et al. (2003) also used this in-vitro method to estimate and rank the bioavailability of iron and other minerals including calcium and zinc from white beans, chickpeas and lentils. Afify et al. (2011) also used this method to measure the iron bioavailability from three white sorghum varieties. According to Forbes et al. (1989), the estimation of iron bioavailability using in-vitro methods are generally ranked similar to those measured in human studies. This suggests that in-vitro methods are useful in comparing and predicting the iron bioavailability in a large number of samples before proceeding to human studies.

However, Pynaert et al. (2006) argued that the iron solubility method was not valid in a study that compared iron bioavailability in infant processed and unprocessed complementary food. This study compared the results obtained by the iron solubility method with gastrointestinal measurements coupled with Caco-2 model with the results obtained from an intervention study with Tanzanian infants. Iron solubility predicted much higher bioavailability in the processed complementary food compared to the unprocessed complementary food. However, these results contrasted with the results of iron status measurements in children who were fed the processed complementary food where no significant differences were observed. This could be due to various reasons including the iron status of the children in the original study, however the author concluded that the iron solubility is a poor predictor of actual iron absorption. In contrast to predictions made from iron solubility data, the results of the Tanzanian intervention study were in agreement with the data generated from the Caco-2 cell model for iron bioavailability. In the intervention study no significant differences were found for growth and iron status parameters between the intervention group and control group fed with unprocessed complementary food.

\section{Iron Dialysability}

In the dialysability method, a dialysis tube is introduced in the small intestinal phase and the amount of iron is measured in the dialysate. In theory, any iron that can be liberated to solution under gastric condition is potentially available for absorption across the intestine, hence the amount of solubilized iron can be used as a measure of bioavailability. This method is often chosen due to its simplicity, cost effectiveness and ease of setting up, however it is only limited to assessment of bioavailability.

The dialysability method as developed by Miller et al. (1981) has been used extensively to predict mineral bioavailability. The main difference of this method is the use of a dialysis membrane during the intestinal phase to mimic the differential epithelial uptake of the low molecular and high molecular weight iron. After the gastric phase, the dialysis bag containing $\mathrm{NaHCO}_{3}$ is introduced which allows the slow increase in $\mathrm{pH}$ before and during intestinal phase which occurs when food leaves the stomach and enter the duodenum. The use of the dialysis bag eliminates the problem encountered when using centrifugation in in-vitro solubility method to separate soluble and insoluble components from complex samples. The dialysable iron is measured at the end of intestinal phase (Cilla et al., 2018).

The study by Argyri et al. (2009) adapted the method introduced by Kapsokefalou and Miller (1991) to develop a new setup for the application of the iron dialysability method. In this setup, six-well plates which can run a parallel digestion over six samples at a time and a ring insert that holds the dialysis membrane are proposed. The other advantage is the use of a smaller volume of $2 \mathrm{ml}$ of samples as compared with the original method which used $20 \mathrm{ml}$ of samples. No significant differences 
were found in the results obtained between the two approaches which suggests that this setup is convenient to use when large number of samples are analyzed. Another study by Luten et al. (1996) used the iron dialysability method of Miller et al. (1981) to test the repeatability and reproducibility of the method. This study modified the version of Miller et al. (1981) by the important parameters that the Miller study missed, such as $\mathrm{pH}$ adjustment.

The dialysability method has also been used in various studies to estimate the iron bioavailability in cereals and legumes, effects of inhibitors and enhancers, different cooking methods and processing of the foods on the bioavailability.

The differences in bioavailability of iron according to different heat treatments (Hemalatha et al., 2007a) and cooking techniques (Sebastiá et al., 2001) on cereals and pulses were observed using this method (Table 2). Hemalatha et al. (2007a) looked at the effects of heat processing using either pressure cooking or microwave heating on iron bioavailability from cereals and pulses consumed in India. Generally, iron bioavailability was significantly enhanced in all cereals and pulses following heat treatment. The iron bioavailability of rice and finger millet were higher after microwaving while wheat, sorghum and maize were higher in pressure cooked treatment. Microwave cooking generally produced an even greater increase in iron bioavailability from decorticated chickpea, whole green gram, red gram, black gram, and cowpea. This information is important as cereals and pulses are mostly consumed in a cooked form with pressure cooking being the most common method.

Similarly, Sebastiá et al. (2001) compared the iron bioavailability in other foods using in-vitro dialysability method. Beans, lentils and chickpeas were included that were commonly consumed and subject to typical household treatments including soaking in water, traditional cooking methods and microwaving as well as legumes that are commercially marketed as ready to eat (RTE). The differences in the conditions are different dialysis molecular weight cut off and a longer incubation in the intestinal phase. Heat treatments, both traditional and microwave cooking, reduced the iron bioavailability except for RTE legumes which gave the highest iron bioavailability. According to the author, the commercially produced legumes are usually soaked in EDTA to protect iron from reacting with phytic acid and therefore, increased the iron bioavailability.

The effects of different soaking techniques either in water, tartaric acid or calcium hydroxide solution and germination from bran and endosperm rich fractions of pearl millet also used the iron dialysability method to assess the iron bioavailability (Jha et al., 2015). The authors found that there was an improvement in bioavailable iron in acid soaked endosperm and bran fractions and this could be attributed to the decrease in phytate content and solubilisation of insoluble fiber. This type of study provides a useful understanding of the effects of pre-treatments that are traditionally used in households on iron bioavailability.

Apart from the study mentioned earlier, the effects of the inhibitors including phytic acid, tannins, calcium and dietary fiber have also been examined using this iron dialysability method. Hemalatha et al. (2007b) looked at the iron bioavailability of widely consumed cereals and pulses in India and its correlation with phytic acid, tannin, calcium, soluble and insoluble fiber contents. The correlation study found that the phytic acid content of the cereal grains produced a proportionate reduction in iron bioavailability, with the exception of sorghum. However, a similar negative influence of phytate on iron bioavailability from pulses was not evident. Insoluble dietary fiber was also found to interfere with iron bioavailability in pulses. In addition, it appeared that tannins did not have any significant influence on iron bioavailability in either cereals or pulses which contradicted the inhibition by tannins and the reason for this is unclear. Effects of phytase treatment on black gram and green gram was shown to lead to significant increases in iron bioavailability.

Sotelo et al. (2010) assessed the effects of oxalate, phytate and tannins on the iron bioavailability of widely consumed leafy vegetables, cereals, legumes and tubers in raw and cooked form and compared it with animal products (beef and chicken liver, beef, chicken and fish) in Mexico. The phytate/iron molar ratio was used in this study to predict the inhibitory effect on the bioavailability of iron. All samples had ratios more than one which indicated that the iron bioavailability would be impaired by phytates present in these foods. This information is useful for computing the recommended dietary allowances to improve the iron intake.

Fortification is one of the public health strategies to increase iron intake to address iron deficiency. This was demonstrated by Tripathi and Platel (2011) who studied the effect of fortification and enhancers on the iron bioavailability of meals made from fortified finger millet flour. The effects of natural enhancers such as ascorbic acid from amla fruit (gooseberry), (252 \pm 34 $\mathrm{mg} / 100 \mathrm{~g}$ ), (Longvah et al., 2017) on the iron bioavailability from cereals and pulses or a combination of cereals and pulses cooked meal were observed and found various effects depending on the food sample and the amount of enhancers present. The addition of 10 and $30 \%$ amla showed an increase of 23 and $75 \%$ of iron bioavailability respectively in wheat. Meanwhile, the addition of $10 \%$ amla in ragi increased the iron bioavailability by $21 \%$. The addition of $30 \%$ amla gave a reduction of 50 and $24 \%$ of iron bioavailability in rice and sorghum respectively. A reduction in iron bioavailability of $28-80 \%$ was observed in all pulses and 37 to $71 \%$ in cereal-pulse combinations with the addition of 10 or $30 \%$ amla. The author suggested that the enhancement effect of ascorbic acid on iron bioavailability in amla fruits is inhibited by the presence of tannin (Gowri et al., 2001). A study by Tuyizere et al. (2021) used an iron dialysability method to estimate the iron bioavailability in various wild fruits and vegetables that are abundant in rural areas of Uganda. This information is regarded as necessary to plan the nutritional intervention to improve the bioavailability of iron from these plant species with the addition of enhancers such as ascorbic acid, as well as the effect of processing to improve the intake of iron in the communities. This shows that the application of in-vitro methods is wide and flexible and could adapt for many types of study.

The molecular weight cut-off of the dialysis bag in the studies presented in this review varied between 8 and $14 \mathrm{kDa}$, also the final $\mathrm{pH}$ adjustment, time of incubation and the method used for iron quantification (Table 2) which makes the comparison between values difficult. 
TABLE 2 | Iron bioavailability studies using in-vitro dialysability methods.

\begin{tabular}{|c|c|c|c|c|c|c|}
\hline \multirow[t]{2}{*}{ Type of study/foods } & \multicolumn{3}{|c|}{ Conditions (pH, incubation time, centrifugation, buffer) } & \multirow[t]{2}{*}{ Iron quantification } & \multirow[t]{2}{*}{ Findings } & \multirow[t]{2}{*}{ References } \\
\hline & Oral phase & Gastric phase & Intestinal phase & & & \\
\hline $\begin{array}{l}\text { Effects of heat processing on iron } \\
\text { bioavailability in rice, finger millet, } \\
\text { sorghum, wheat, maize, chickpea, } \\
\text { whole and decorticated green } \\
\text { gram, whole and decorticated black } \\
\text { gram, decorticated red gram, } \\
\text { cowpea and French bean }\end{array}$ & - & Pepsin, $\mathrm{pH} 2,37^{\circ} \mathrm{C}, 2 \mathrm{~h}$ & $\begin{array}{l}\text { Dialysis tube (cut off } 10 \\
\mathrm{kDa} \text { ) containing } 25 \mathrm{ml} \\
\text { sodium bicarbonate } \\
\text { solution, pancreatine-bile } \\
\text { mixture, } \mathrm{pH} 737^{\circ} \mathrm{C} \text { for } 2 \mathrm{~h}\end{array}$ & AAS & $\begin{array}{l}\text { Bioavailability (\%) } \\
\text { Raw } \\
\text { Rice: } 8.05 \\
\text { Wheat } 5.06 \\
\text { Finger millet: } 6.61 \\
\text { Sorghum: } 4.13 \\
\text { Maize: } 7.83 \\
\text { Whole/decorticated } \\
\text { chickpea: } 6.89 / 4.82 \\
\text { Whole/decorticated green } \\
\text { gram: } 2.24 / 7.49 \\
\text { Decorticated red gram: } 3.06 \\
\text { Decorticated black gram: } 2.76 \\
\text { Cowpea: } 1.77 \\
\text { French bean: } 10.2 \\
\text { Pressure cooked Rice: } 12 \\
\text { Wheat } 7.03 \\
\text { Finger millet: } 7.37 \\
\text { Sorghum: } 7.24 \\
\text { Maize: } 9.53 \\
\text { Whole/decorticated } \\
\text { chickpea: } 8.01 / 4.25 \\
\text { Whole/decorticated green } \\
\text { gram: } 2.43 / 8.48 \\
\text { Decorticated red gram: } 4.51 \\
\text { Decorticated black gram: } 2.40 \\
\text { Cowpea: } 3.98 \\
\text { French bean: } 11.8 \\
\text { Microwave cooked Rice: } 24.1 \\
\text { Wheat: } 5.64 \\
\text { Finger millet: } 12.2 \\
\text { Sorghum: } 2.31 \\
\text { Maize: } 6.43 \\
\text { Whole/decorticated } \\
\text { chickpea: } 5.31 / 9.06 \\
\text { Whole/decorticated green } \\
\text { gram: } 4.84 / 6.51 \\
\text { Decorticated red gram: } 7.64 \\
\text { Decorticated black gram: } 7.12 \\
\text { Cowpea: } 5.63 \\
\text { French bean: } 4.05 \\
\end{array}$ & $\begin{array}{l}\text { Hemalatha et al. } \\
\text { (2007a) }\end{array}$ \\
\hline $\begin{array}{l}\text { Effects of calcium, phytate, tannin } \\
\text { and fibers on iron bioavailability in } \\
\text { rice, finger millet, sorghum, wheat, } \\
\text { maize, chickpea whole and } \\
\text { decorticated, whole and } \\
\text { decorticated green gram, black } \\
\text { gram, red gram, cowpea and } \\
\text { French bean }\end{array}$ & - & Pepsin, $\mathrm{pH} 2,37^{\circ} \mathrm{C}, 2 \mathrm{~h}$ & $\begin{array}{l}\text { Dialysis tube (cut off } 10 \\
\mathrm{kDa} \text { ) containing } 25 \mathrm{ml} \\
\text { sodium bicarbonate } \\
\text { solution, pancreatine-bile } \\
\text { mixture, } \mathrm{pH} 737^{\circ} \mathrm{C} \text { for } 2 \mathrm{~h}\end{array}$ & AAS & $\begin{array}{l}\text { Bioavailability (\%) } \\
\text { Rice: } 8.05 \\
\text { Finger millet: } 6.61 \\
\text { Sorghum: } 4.13 \\
\text { Wheat } 5.06 \\
\text { Maize: } 7.83 \\
\text { Whole/decorticated } \\
\text { chickpea: } 6.89 / 4.82\end{array}$ & $\begin{array}{l}\text { Hemalatha et al. } \\
\text { (2007b) }\end{array}$ \\
\hline
\end{tabular}




Oral phase

Intestinal phase

Whole/decorticated green

gram: 2.25/7.49

Black gram: 2.76

Red gram: 3.06

Cowpea: 1.77

French bean: 10.2

Effects of different processing on

Pepsin, $\mathrm{pH}$ 2, $2 \mathrm{~h}$

Dialysis tube (cut-off

Iron bioavailability from white beans,

12-14 kDa) containing

chickpeas, lentils and ready to eat

$25 \mathrm{ml}$ of water and an

amount of

sodium bicarbonate

$37^{\circ} \mathrm{C}$ for $90 \mathrm{~min}$

Effects of enhancers (ascorbic

acid/amla fruit) on iron bioavailability

of cooked samples from cereal,

Dialysis tube (cut off 10

$\mathrm{kDa}$ ) containing $25 \mathrm{ml}$

ICP-ES

wheat and pulses

sodium bicarbonate

solution, pancreatine-bile

mixture $\mathrm{pH} 737^{\circ} \mathrm{C}$ for $2 \mathrm{~h}$
Bioavailability $(\mu \mathrm{g} / \mathrm{g})$

White bean

Sebastia et al.

Raw 0.045

Traditional 0.017

Microwave- RTE 0.46

Chickpea

Raw 0.025

Traditional 0.026

Microwave 0.027

RTE 0.41

Lentils

Raw 0.025

Traditional 0.017

Microwave 0.02

RTE 0.45

Bioavailability after the

additions (None, Amla 10\%,

Amla 30\%, Ascorbic acid

$0.05 \%$ respectively)

Rice: $9.52,7.32,4.77,11.94$

Ragi: $0.84,1.02,0.67,1.23$

Wheat: $1.88,2.32,3.20,2.00$

Jowar: 3.40, 3.40, 2.59, 6.13

Black gram dhal: 2.18, 1.26,

$1.20,2.77$

Red gram dhal: $3 / 27,0.65$,

$0.85,4.32,3.32$

Green gram dhal: 3.32, 2.38,

1.05, 6.89

Bengal gram dhal: 5.89, 1.54,

1.50, 7.06

Rice + black gram dhal (2:1):

8.52, 4.18, 3.97, 12.94

Ragi + red gram dhal (4:1):

$1.39,0.88,0.69,2.04$

Wheat + green gram dhal

(4:1): 1.96, 0.64, 0.57, 2.20

Jowar + bengal gram dhal

(4:1): $2.47,1.30,1.26,2.38$ 
Iron quantification

Oral phase Gastric phase

Intestinal phase

processing on iron bioavailability in finger millet flour and finger millet-based foods (dumpling and roti)

Pepsin, $\mathrm{pH} 2,37^{\circ} \mathrm{C}, 2 \mathrm{~h}$

Dialysis tube (cut off 10 $\mathrm{kDa}$ ) containing $25 \mathrm{ml}$ sodium bicarbonate

solution, pancreatine-bile mixture $\mathrm{pH} 737^{\circ} \mathrm{C}$ for $3 \mathrm{~h}$ or longer until the $\mathrm{pH}$ of the digest reached $7.5 \%$ nitric acid was added to the dialysate, centrifuged then filtered

Assessing iron bioavailability in plan and animal foods in Mexican diets and effects of inhibitors on the iron bioavailability

\section{Effects of soaking and germination} on different grain fraction from finger millet

Fruits and vegetables consumed in Uganda
Pepsin, $\mathrm{pH} 2,37^{\circ} \mathrm{C}, 2 \mathrm{~h}$

Dialysis tube (cut off 8 $\mathrm{kDa}$ ) containing $25 \mathrm{~m}$ sodium bicarbonate

solution, pancreatine-bile mixture $\mathrm{pH} 537^{\circ} \mathrm{C}$ for $2 \mathrm{~h}$ HCL was added to dialysate and adjusted the volume to $25 \mathrm{ml}$ before measurement

Pepsin, $\mathrm{pH} 2,37^{\circ} \mathrm{C}, 2 \mathrm{~h}$

Dialysis tube (cut off 8-12 $\mathrm{kDa}$ ) containing $25 \mathrm{~m}$ sodium bicarbonate solution, $37^{\circ} \mathrm{C}$ for $30 \mathrm{~min}$ then pancreatin-bile mixture was added and shaken for $2 \mathrm{~h}$ until the $\mathrm{pH}$ reached 7

Pepsin, $\mathrm{pH} 2,37^{\circ} \mathrm{C}, 2 \mathrm{~h}$

Dialysis tube (cut off 10 $\mathrm{kDa}$ ) containing $25 \mathrm{ml}$ sodium bicarbonate

solution, pancreatine-bile mixture $\mathrm{pH} 737^{\circ} \mathrm{C}$ for $2 \mathrm{~h}$

Heat processing of the

fortified and unfortified flour

improved the

bioavailability $(\mathrm{mg} / \mathrm{g})$

Unfortified flour: 0.23

$\mathrm{mg} / 100 \mathrm{~g}$ to $0.50 \mathrm{mg} / 100 \mathrm{~g}$

Dumpling co-fortified with

EDTA: $2.25 \mathrm{mg} / 100 \mathrm{~g}$

Roti co-fortified with EDTA:

$2.39 \mathrm{mg} / 100 \mathrm{~g}$

Flour fortified with EDTA

shows increase

in bioavailability

Spectrophotometer at $530 \mathrm{~nm}$

Bioavailability $(\mathrm{mg} / \mathrm{g})$

Leafy vegetables

Cooked 1.98-4.45 mg/100 g

Cereals

Raw $2.62-2.93 \mathrm{mg} / 100 \mathrm{~g}$

Cooked 2.56-3.08 mg/100 g

Legume and tubers

Raw 2.11-3.56 mg/100 g

Cooked 2.45-3.56 mg/100 g

Animal products

Raw 7.27-9.8 mg/100 g

Cooked 7.30-9.79 mg/100 g

Bioavailability (\%)

Bran rich

fraction: $19.8-25.71 \%$

Endosperm rich

fraction: $8.26-13.18 \%$

\section{Bioavailability (\%)}

Wild fruits

Oywello (17.93), Oceyo

(15.14), Kalara (22.91),

Tongogwal Madito (2.65),

Kano (15.61), Tugu (0.81)

Wild vegetables

Gwanya (9.80), Obuga lum

(22.65), Oyado (10.15), Pot

kalara (6.15), Otigo lum/nyim

(18.37), Malakwang Odwonga

(12.36), Boo ayom (12.51),

Layika (27.65) and

Ayuyu (13.83)
Sotelo et al.

Tripathi and

Platel (2011)

Jha et al. (2015)

Tuyizere et al.

(2021) 
TABLE 3 | Iron bioavailability study using gastrointestinal models.

\begin{tabular}{|c|c|c|c|c|c|c|}
\hline \multirow[t]{2}{*}{ Type of study/foods } & \multicolumn{3}{|c|}{ Conditions (pH, incubation time, centrifugation, buffer) } & \multirow[t]{2}{*}{ Iron quantification } & \multirow[t]{2}{*}{ Findings } & \multirow[t]{2}{*}{ References } \\
\hline & Oral phase & Gastric phase & Intestinal phase & & & \\
\hline $\begin{array}{l}\text { Effects of household process on the } \\
\text { iron bioavailability from black bean } \\
\text { samples (raw, pressure cooker, } \\
\text { regular pan) }\end{array}$ & Gl and dialysis membrane & $\begin{array}{l}10 \mathrm{~g} \text { of ground sample } \\
\text { were suspended in } 60 \mathrm{ml} \\
\text { of } 20 \mathrm{mM} \text { glycine- } \mathrm{HCl} \\
\text { buffer, } \mathrm{pH} 2,1.3 \mathrm{ml} \text { of } \\
\text { pepsin (porcine), }(1.6 \mathrm{~g} \\
\text { pepsin in } 10 \mathrm{ml} 20 \mathrm{mM} \\
\text { glycine- } \mathrm{HCl} \text { buffer, } \mathrm{pH} \\
2.0), 37^{\circ} \mathrm{C}, 2 \mathrm{~h}\end{array}$ & $\begin{array}{l}\mathrm{pH} 7.2 \text { with } 1 \mathrm{M} \mathrm{NaHCO}_{3} \text {, } \\
\text { pancreatine porcine } 13 \mathrm{ml} \\
\text { of a pancreatin porcine } \\
(0.4 \mathrm{~g} \text { pancreatin in } 100 \mathrm{ml} \\
\text { of ultrapure water) a } \\
\text { dialysis bag (cut of } 10,000 \\
\text { Da with } 2 \mathrm{ml} \text { water) was } \\
\text { placed in the digestion } \\
\text { system, } 37^{\circ} \mathrm{C}, 2 \mathrm{~h}\end{array}$ & $\begin{array}{l}\text { Iron in the dialysate were } \\
\text { analyzed by ICP-MS }\end{array}$ & $\begin{array}{l}\text { Bioavailability }(\%) \\
\text { Regular pan with soaking } \\
\text { water: } 0.18 \% \\
\text { Pressure cooker with } \\
\text { soaking water: } 0.33 \% \\
\text { Regular pan without } \\
\text { soaking water: } 0.17 \% \\
\text { Pressure cooker without } \\
\text { soaking water: } 0.22 \%\end{array}$ & $\begin{array}{l}\text { Feitosa et al. } \\
\text { (2018) }\end{array}$ \\
\hline $\begin{array}{l}\text { Investigating the effects of } \\
\text { bio-fortification in iron bioavailability } \\
\text { and bioavailability from cowpea } \\
\text { cultivars and non-biofortified beans }\end{array}$ & $\begin{array}{l}200 \mathrm{mg} .200 \mu \mathrm{l} \text { of the } 1 \% \\
(\mathrm{w} / \mathrm{v}) \alpha \text {-amylase solution in } \\
\mathrm{NaHCO}_{3} \text { buffer, } \mathrm{pH} 6.8 \\
\text { Enzymes sources were } \\
\text { not indicated }\end{array}$ & $\begin{array}{l}3 \mathrm{ml} \text { of a } 0.5 \%(\mathrm{w} / \mathrm{v}) \mathrm{pH} \\
1.2 \text { pepsin, } 2 \mathrm{~h} \text { at } 37^{\circ} \mathrm{C}\end{array}$ & $\begin{array}{l}3 \mathrm{~mL} \text { of a } 3 \%(\mathrm{w} / \mathrm{v}) \\
\text { pancreatin solution and } \\
2.5 \%(\mathrm{w} / \mathrm{v}) \text { bile salts in } \\
\mathrm{NaHCO}_{3} \text { buffer } \mathrm{pH} 7.4 \text {, } \\
\mathrm{pH} \text { to } 7.4 \text {. A dialysis } \\
\text { membrane }(14 \mathrm{kDa} \\
\mathrm{MWCO} \text { filled with } \\
\left.\mathrm{NaHCO}_{3} \mathrm{pH} 7.4\right) \text { was } \\
\text { inserted into the tube, } 2 \mathrm{~h} \\
\text { at } 37^{\circ} \mathrm{C}\end{array}$ & $\begin{array}{l}\text { ICP-MS } \\
\text { Dialysate (solution from } \\
\text { the dialysis membrane) } \\
\text { Soluble (supernatant after } \\
\text { centrifuged at 3,000 rpm) }\end{array}$ & $\begin{array}{l}\text { Bioavailability (\%) } \\
\text { Dialysate fraction } \\
\text { Biofortified } \\
\text { cowpea cultivars: } \\
\text { ARA 3.5\%, TUM 3.3\%, } \\
\text { XIQ 3.8\% } \\
\text { Non-biofortified } \\
\text { GUA 5.8\% } \\
\text { Common beans cultivars: } \\
\text { CAR 1.2\% } \\
\text { WHI 2.8\% } \\
\text { GRE 1.5\% } \\
\text { BLA 0.9\% } \\
\text { Soluble fraction } \\
\text { Biofortified ARA 52.3\%, } \\
\text { TUM 46.6\%, XIQ 32.5\% } \\
\text { Non-biofortified } \\
\text { GUA 54.3\% } \\
\text { Common beans cultivars: } \\
\text { CAR 13.7\% } \\
\text { WHI 30.3\% } \\
\text { GRE 25.7\% } \\
\text { BLA 12.7\% }\end{array}$ & $\begin{array}{l}\text { Coelho et al. } \\
\text { (2021) }\end{array}$ \\
\hline $\begin{array}{l}{ }^{a} \text { Effects of fermentation and } \\
\text { cooking on iron bioavailability from } \\
\text { finger millet sour porridge using } \\
\text { INFOGEST static }\end{array}$ & STATIC INFOGEST & & $\begin{array}{l}\text { The conditions were } \\
\text { similar except the use of } \\
\text { dialysis bag during the } \\
\text { intestinal phase containing } \\
\mathrm{NaCl} \text { and } \mathrm{NaHCO}_{3}\end{array}$ & ICP-OES & $\begin{array}{l}\text { Bioavailability } \\
\text { Flour } 7.7 \% / 0.065 \mathrm{mg} / 100 \\
\mathrm{~g} \mathrm{dm} \\
\text { SFS } 5.7 \% / 0.056 \mathrm{mg} / 100 \\
\mathrm{~g} \mathrm{dm} \\
\text { SFP } 6.1 \% / 0.066 \mathrm{mg} / 100 \\
\mathrm{~g} \mathrm{dm}\end{array}$ & $\begin{array}{l}\text { Gabaza et al. } \\
\text { (2018) }\end{array}$ \\
\hline $\begin{array}{l}{ }^{a} \text { Effects of coking on iron } \\
\text { bioavailability in whole and dehulled } \\
\text { Bambara groundnut }\end{array}$ & STATIC INFOGEST & & & ICP-OES & $\begin{array}{l}\text { Bioavailability (\%) } \\
\text { 16-24\% in whole } \\
\text { and dehulled }\end{array}$ & $\begin{array}{l}\text { Gwala et al. } \\
(2020)\end{array}$ \\
\hline
\end{tabular}




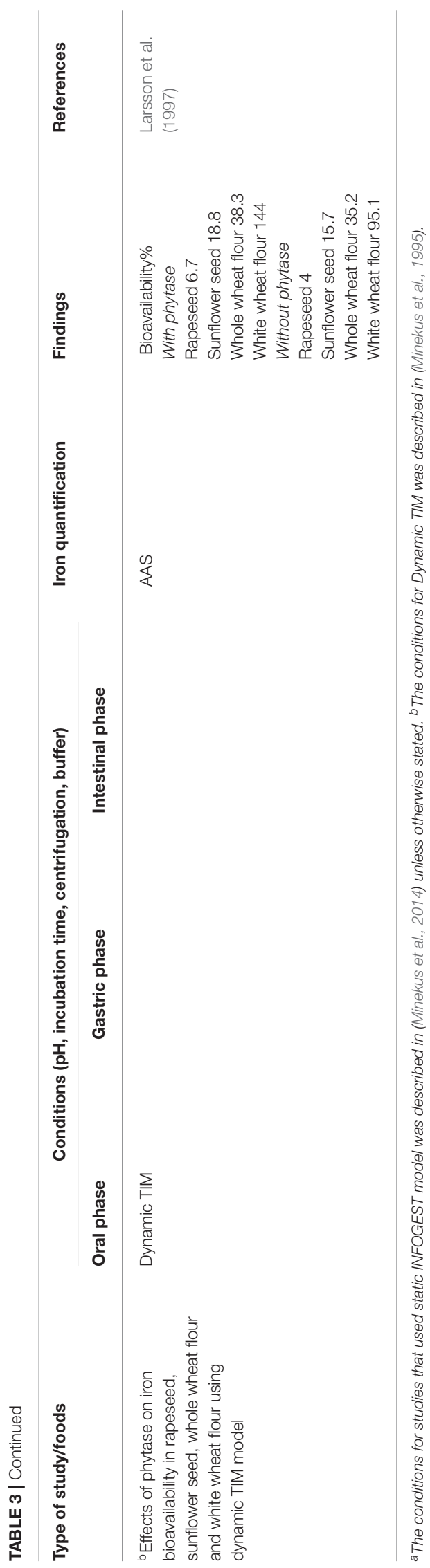

One of the general limitations of the dialysis technique is that large molecules such as haem iron or ferritin would be bioavailable but not dialysable as they could not diffuse through the membrane, but some smaller compounds like phenolic complexes or complexes with organic acids can diffuse through the membrane but generally would not be bioavailable. This limitation can be overcome by coupling this method with cell culture (Bohn et al., 2018).

All the studies presented above used a static model which did not simulate the gastric emptying or continuous changes in $\mathrm{pH}$ and secretion flow rates.

\section{Gastrointestinal Model}

Gastrointestinal models are in-vitro methods that are designed to simulate the human digestive system. There have been various models that differ in terms of the apparatus, enzyme concentrations and activity, digestion time, simulated digestion fluids, the ratio of sample to buffer etc.

A study by Larsson et al. (1997) adapted the TNO Gastro-Intestinal Model (TIM), a multicompartmental dynamic gastrointestinal model developed by Minekus et al. (1995) to investigate the effects of phytate on the iron absorption from wheat flour, whole wheat flour, rapeseed and sunflower seed and was then compared with the data obtained from human and animal studies. The addition of exogenous phytase improved the amount of dialyzed iron in all samples. This model consisted of four compartments to simulate the stomach, duodenum, jejunum and ileum. The model was equipped with a computer program to regulate the parameters such as $\mathrm{pH}$ for stomach and duodenum, secretion rates of gastric and duodenal juice into different compartments. The gastric and duodenal parts are equipped with $\mathrm{pH}$ electrodes to control the $\mathrm{pH}$ values for the stomach and duodenum. The advantage of this in-vitro dynamic model is that it resembles more closely the in-vivo physiological parameters simulating the dynamic condition of stomach and small intestine with peristaltic movements, absorption of nutrients, physiological emptying patterns and transit times. The bioavailability of minerals was measured from the proportion of compounds that dilutes across the hollow fiber system which contains a dialysis membrane with a molecular weight cutoff of $10 \mathrm{kDa}$ connected to the jejunal and ileal compartments during the intestinal passage (Minekus, 2015).

A more recent method called the INFOGEST static model was developed by Minekus et al. (2014) and is receiving attention due to its general standardized protocol. This includes the use of enzyme sources, $\mathrm{pH}$, ionic strength, electrolytes used, bile, dilution and digestion time. This static model uses a constant ratio of food to enzymes, electrolytes, and constant $\mathrm{pH}$ for each digestive phase and was developed recently to allow comparisons of food digestibility and micronutrient bioavailability between laboratories (Minekus et al., 2014; Brodkorb et al., 2019).

As mentioned previously, iron content does not always reflect the value of bioavailability due to some level of mineral chelation with inhibitors such as phytates and polyphenols. Gwala et al. (2020) used the INFOGEST model to evaluate the iron bioavailability in whole and dehulled Bambara groundnut. They found that the amount of bioavailable iron was about 
$14-20 \%$ of the total iron content in raw and cooked samples (Table 3).

Gabaza et al. (2018) examined the effect of fermentation and cooking on iron bioavailability of finger millet sour porridge produced at different households. The study used the static INFOGEST model as proposed by Minekus et al. (2014) with some modifications; the introduction of a dialysis bag into the digestion vessel with a molecular weight cutoff of 12 to $14 \mathrm{kDa}$ containing a mixture of sodium chloride and sodium bicarbonate after $1.5 \mathrm{~h}$ of gastric phase. In this study, two different fractions of iron were measured. The first fraction was the fluid in the dialysis bag which was denoted as dialysable iron and the other fraction was the soluble part obtained from the digested mixture after centrifugation namely soluble nondialysable iron fraction. Both fractions were used as the total soluble iron. The author found no significant improvement on the iron bioavailability of flour, spontaneous fermented slurries (SFS) and spontaneous fermented porridge (SFP) which were 7.7, 5.7 and $6.1 \%$ respectively (Table 3 ). The bioavailable iron content was $0.065,0.056$ and $0.066 \mathrm{mg} / 200 \mathrm{~g}$ dry matter for flour, SSF and SFP respectively. The author argued that the reason fermentation did not lead to any improvement on the iron bioavailability was due to traditional fermentation that was highly variable and unpredictable in household practice. In some cases, fermentation is normally aided by pre-processing such as decortication, soaking and germination. This type of study is again useful to provide baseline knowledge for future intervention and that the iron content and bioavailability from fermentation product may not be generalized.

Interestingly, a recent study by Muleya et al. (2021) used a modified static INFOGEST model by using an isotope labeling of reagent iron $\left({ }^{57} \mathrm{Fe}\right)$ to evaluate the contribution of iron in reagents used in the INFOGEST method in relation to iron in sample and the possible interference of reagent-derived iron with the bioavailability measurement in cereals and legumes. During in-vitro digestion, iron from samples and reagents enter a common pool that undergoes the same interactions that influence bioavailability. The stable isotope approach was compared with two normally used approaches to calculate iron bioavailability. The first approach used blank correction in order to obtain the iron bioavailability in the dialysate fraction while the second approach did not and the iron bioavailability was determined in all fractions. The author suggested that the use of isotopic labeling of reagent iron results in accurate and reliable iron bioavailability measurements particularly when analyzing samples with lower iron content than the iron in the reagents particularly in cereals and legumes.

There were studies that used different gastrointestinal models to the INFOGEST model to measure the iron bioavailability as demonstrated by Feitosa et al. (2018) and Coelho et al. (2021). Both studies used different concentration of digestive enzymes, duration of digestion, $\mathrm{pH}$ values and buffer concentrations in the different phase of digestion (Table 3). These two studies used the dialysis bag in the small intestinal phase.

Feitosa et al. (2018) explored the effects of household processing by two cooking methods, boiling in a regular pan and pressure cooking with or without the water the black beans were soaked in. The study found that the iron bioavailability from black beans. The study found that the iron bioavailability in both processes was low $(0.18-0.33 \%)$ and beans cooked with soaking water in a pressure cooker resulted in the highest iron bioavailability $(0.22 \%)$. The knowledge of applying the most efficient household procedures is important to ensure that the iron bioavailability is optimal after cooking.

Coelho et al. (2021) investigated the effects of bio-fortification on the iron bioavailability from bio-fortified cowpea cultivars BRS Xiquexique (XIQ), BRS Tumucumaque (TUM) and BRS Aracê (ARA) and non-biofortified BRS Guariba (GUA), common Black (BLA), White (WHI), Carioca (CAR) and Green (GRE) bean cultivars in raw and cooked form. The protocol consisted of three steps including oral, gastric and intestinal phase. This study expressed the iron concentration as a bio-accessible (soluble supernatant obtained after centrifugation) and bioavailability (dialysate) fractions. However, since bioavailability term has been used throughout the review, the bio-accessible fraction will be known as bioavailability from soluble fraction and the other fraction will be bioavailability from the dialysate. Bio-fortification did improve the iron bioavailability but not in all cowpea cultivars (Table 3). Non-bio-fortified GUA showed high bioavailability in both fractions. The iron bioavailability for cowpea cultivars were higher (32.5-54.3\%) than common beans (12.7-30.9\%) in bioavailability from soluble fraction. Similarly, from the fractions, cowpea cultivars (3.5-5.8\%) showed higher iron bioavailability compared to common beans (0.9-2.8\%). Cooking showed an increase in the bioavailability of dialysate fractions in TUM biofortified cowpea, green and black common beans. Cooking may have reduced the polyphenol content, however, the differential effects of cooking on different cultivars is unclear but it may be related to different polyphenol content in different cultivars. This in-vitro study is useful to demonstrate the effectiveness of crop breeding program before moving on to evaluate in-vivo the beneficial effects of the bio-fortified crop.

\section{Cell Culture}

This method is normally coupled with either solubility, dialysability or a gastrointestinal model. This assay measures iron uptake via ferritin formation in a monolayer of Caco-2 cells after the food sample is digested. Caco-2 cells are human epithelial cell line derived from a human colonic adenocarcinoma which behaves like intestinal cells. The advantage of these combined methods is that they can be used to study the mechanism of iron uptake and transport.

Yun et al. (2004) demonstrated the use of in-vitro digestion coupled with a Caco-2 cell model to replicate meals fed in human studies (egg meals with varying ascorbic acid concentration and wheat rolls with varying tannic acid concentration) to determine how the cell culture reflects to the iron bioavailability measured in human trials. Ferritin formation by the Caco-2 cells, which serves as a marker for cell iron uptake was used as an indicator of iron bioavailability. This study observed a strong correlation between this model and human trials. A significant correlation between iron uptake by Caco- 2 cells from the meals and human 
absorption was observed $(R=0.934, p=0.012$ for an ascorbic acid added meal and $R=0.927, p=0.007$ for a tannic acid added meal).

In-vitro model coupled with Caco-2 cell was used to measure the iron bioavailability from eight common beans bean genotypes under three conditions: whole cooked beans containing polyphenols, cotyledon (beans without seed coats) without polyphenols and cotyledon without polyphenols with extrinsic ascorbate. The Caco-2 cell ferritin formation for the whole cooked beans ranged from 1.1 to $11.5 \mathrm{ng}$ ferritin/mg protein. Higher ferritin formation was observed in the cooked cotyledon without polyphenol which ranged between 10.8 and $31.9 \mathrm{ng}$ ferritin/mg protein. In the cooked cotyledon with added ascorbate, the ferritin formation ranged between 67.8 and $147.9 \mathrm{ng}$ ferritin/mg protein (Ariza-Nieto et al., 2007). According to the author, the phosphorylated sugars chelate iron with higher avidity than non-phosphorylated forms. This complexation improves the iron solubility during digestion thus increasing the uptake by the cells. However, the increase in iron uptake is only observed at high concentration of sugar as the fructose only chelates iron above a threshold ratio which in this study used iron:sugar ratio of 1:200. As demonstrated in the study, the iron bioavailability varies among common bean genotypes suggesting that the iron bioavailability is genotype dependent and the removal of the seed coat and associated polyphenols improved the iron bioavailability.

This model can also be used to study the interactions between iron and enhancers or inhibitors. For example, it was recently demonstrated that the relative bioavailability of iron is higher in cabbage followed by broccoli, pepper, kale and spinach. This study also showed that the higher iron bioavailability in cabbage could result from the formation of complexes with fructose present in cabbage. In order to determine the effect of fructose on iron uptake in Caco-2 cell, fructose 1,6-biphosphate (F16BP) was added to iron and this led to an increase in ferritin formation in Caco-2 cells (Rodriguez-Ramiro et al., 2019).

Khoja et al. (2021) explored the iron bioavailability in fenugreek, boaba and moringa which have been used for medicinal purposes which could be potential sources of iron. The study used in-vitro digestion followed by iron uptake in Caco- 2 cells to evaluate the iron bioavailability from these plant sources. The iron uptake by Caco- 2 cells from fenugreek sprouts, fenugreek seeds, baobab fruit pulp and moringa leaves were about 20, 7, 3 and $10 \mathrm{ng}$ ferritin/mg protein.

\section{BENEFITS AND LIMITATION OF in-vitro METHODS AND RECOMMENDATIONS}

Though human studies are still recognized as the gold standard for evaluating iron bioavailability, in-vitro methods appear to be an alternative method to estimate the iron bioavailability in plant-based foods prior to human studies. This is because invitro methods have been found to be reliable indicators of iron bioavailability with good reproducibility if all the experimental conditions are taken into account between different studies. For example Aragón et al. (2012) compared the validity of an iron dialysability method with in-vivo data to assess the iron bioavailability from staple biofortified food crops. The first recipe was to assess the effect of iron bioavailability with different concentration of ascorbic acid in a meal. The second recipe was to evaluate the effects of iron absorption promoters $\mathrm{Na}_{2}$ EDTA and the fortificants ferrous fumarate, ferrous sulfate and NaFeEDTA in tortillas. The in-vitro dialysability results showed a similar trend to the in-vivo results which used these recipes to feed the subjects and were highly and statistically correlated. The study also found that the results from the in-vitro method yielded more statistically significant differences between treatments than the in-vivo. This can be explained by reduced variability in the data compared to in-vivo.

An additional benefit is that there are no differences in baseline iron status such as can be seen in human studies which results in high variability in iron bioavailability as compared to in-vitro methods as observed in the study of (Aragón et al., 2012). As outlined above, there was great variation in the conditions of the in-vitro methods as discussed in this review. This demonstrates that the in-vitro models provide better control over conditions of the experiments which may lead to precise and reproducible results. It is also simple, rapid and low cost and many samples can be evaluated at one time.

There are also limitations of in-vitro methods that should be addressed. A study by (Mamiro et al., 2004) showed that reduction of phytate content of a complementary cereal-based food (from 1,150 to $660 \mathrm{mg} / 100 \mathrm{~g}$ ) led to an increase in invitro iron solubility from 4.8 to $18.8 \%$ but showed no effect on hemoglobin status of infants of 6 to 12 months of age. So, an increase iron bioavailability measured by an in-vitro solubility method in processed food does not guarantee an increase in iron absorption and therefore in iron status of humans consuming phytate containing foods. These discrepancies between invivo and in-vitro studies may be attributed to the absence of simulation of the intestinal absorption and the physiological regulation mechanisms in the in-vitro digestion systems. This could also be explained by an adequate iron status of the infants at baseline.

It is still important to recognize that despite human studies being rather time consuming, expensive and complicated to perform, in-vivo measurement is necessary to assess the human factors affecting iron uptake. However, if the main interest is on the relative value of iron bioavailability from different plant sources and processing, in-vitro can be considered as a better option.

\section{CONCLUSIONS}

It is clear from this review that in-vitro methods are an important tool for preliminary screening that helps to assess the iron bioavailability in range of foods and staple crops, effect of processing conditions, assess the effects of inhibitors on iron bioavailability and other approaches such as fortification to improve iron bioavailability. Though, as mentioned, the results from in-vitro measurements have been shown to provide a 
useful estimate of in-vivo estimates of iron bio-accessibility or bioavailability. Whilst there have been great variations in in-vitro methodologies, they are useful for comparing and classifying foods according to the bioavailability. Clearly, there is a diverse use of in-vitro methods described in this review. This means that the use of in-vitro methods allows the possibility to control or modify the conditions of the experiment depending on the aim of the study. It also offers the possibility to optimally control the conditions which can lead to high accuracy. However, in order to compare the values or establish a food classification according to iron bioavailability, the standardization of the conditions of the assay is needed as demonstrated by the INFOGEST

\section{REFERENCES}

Afify, A. E.-M. M., El-Beltagi, H. S., Abd El-Salam, S. M., and Omran, A. A. (2011). Bioavailability of iron, zinc, phytate and phytase activity during soaking and germination of white sorghum varieties. PLoS ONE 6:e25512. doi: 10.1371/journal.pone.0025512

Aragón, I. J., Ortiz, D., and Pachón, H. (2012). Comparison between in vitro and in vivo methods to screen iron bioavailability. CyTA-J. Food 10, 103-111. doi: 10.1080/19476337.2011.596283

Argyri, K., Birba, A., Miller, D., Komaitis, M., and Kapsokefalou, M. (2009). Predicting relative concentrations of bioavailable iron in foods using in vitro digestion: new developments. Food Chem. 113, 602-607. doi: 10.1016/j.foodchem.2008.07.089

Ariza-Nieto, M., Blair, M. W., Welch, R. M., and Glahn, R. P. (2007). Screening of iron bioavailability patterns in eight bean (Phaseolus vulgaris L.) genotypes using the Caco-2 cell in vitro model. J. Agric. Food Chem. 55, 7950-7956. doi: 10.1021/jf070023y

Blanco-Rojo, R., and Vaquero, M. P. (2019). Iron bioavailability from food fortification to precision nutrition. Innov. Food Sci. Emerg. Technol. 51, 126-138. doi: 10.1016/j.ifset.2018.04.015

Bohn, T., Carriere, F., Day, L., Deglaire, A., Egger, L., Freitas, D., et al. (2018). Correlation between in vitro and in vivo data on food digestion. What can we predict with static in vitro digestion models? Crit. Rev. Food Sci. Nutr. 58, 2239-2261. doi: 10.1080/10408398.2017.1315362

Brodkorb, A., Egger, L., Alminger, M., Alvito, P., Assunção, R., Ballance, S., et al. (2019). INFOGEST static in vitro simulation of gastrointestinal food digestion. Nat. Protoc. 14, 991-1014. doi: 10.1038/s41596-018-0119-1

Cilla, A., López-García, G., and Barberá, R. (2018). In vitro bioavailability of iron and calcium in cereals and derivatives: a review. Food Rev. Int. 34, 1-33. doi: 10.1080/87559129.2016.1210631

Coelho, R. C., Barsotti, R. C. F., Maltez, H. F., Júnior, C. A. L., and de Sousa Barbosa, H. (2021). Expanding information on the bioaccessibility and bioavailability of iron and zinc in biofortified cowpea seeds. Food Chem. 347:129027. doi: 10.1016/j.foodchem.2021.1 29027

Etcheverry, P., Grusak, M. A., and Fleige, L. E. (2012). Application of in vitro bioaccessibility and bioavailability methods for calcium, carotenoids, folate, iron, magnesium, polyphenols, zinc, and vitamins B6, B12, D, and E. Front. Physiol. 3:317. doi: 10.3389/fphys.2012.00317

Feitosa, S., Greiner, R., Meinhardt, A.-K., Müller, A., Almeida, D. T., and Posten, C. (2018). Effect of traditional household processes on iron, zinc and copper bioaccessibility in black bean (Phaseolus vulgaris L.). Foods 7:123. doi: $10.3390 /$ foods 7080123

Ferruzzi, M. G., Kruger, J., Mohamedshah, Z., Debelo, H., and Taylor, J. R. (2020). Insights from in vitro exploration of factors influencing iron, zinc and provitamin A carotenoid bioaccessibility and intestinal absorption from cereals. J. Cereal Sci. 96:103126. doi: 10.1016/j.jcs.2020. 103126

Forbes, A. L., Arnaud, M., Chichester, C., Cook, J., Harrison, B., Hurrell, R., et al. (1989). Comparison of in vitro, animal, and clinical determinations of iron bioavailability: international nutritional anemia consultative group harmonized method. The in-vitro methods are also useful to predict the bioavailability of iron in commonly consumed foods to underpin the dietary recommendations for alleviating iron deficiency anemia.

\section{AUTHOR CONTRIBUTIONS}

NS wrote the first draft of the manuscript. DG and SA provided constructive feedback, contributed to manuscript revision, read, and approved the submitted version. All authors contributed to the article and approved the submitted version. task force report on iron bioavailability. Am. J. Clin. Nutr. 49, 225-238. doi: 10.1093/ajen/49.2.225

Gabaza, M., Shumoy, H., Louwagie, L., Muchuweti, M., Vandamme, P., Du Laing, G., et al. (2018). Traditional fermentation and cooking of finger millet: implications on mineral binders and subsequent bioaccessibility. J. Food Compost. Anal. 68, 87-94. doi: 10.1016/j.jfca.2017.05.011

Glahn, R. P., and Noh, H. (2021). Redefining bean iron biofortification: a review of the evidence for moving to a high Fe bioavailability approach. Front. Sustain. Food Syst. 5:215. doi: 10.3389/fsufs.2021.682130

Glahn, R. P., Tako, E., Cichy, K., and Wiesinger, J. (2016). The cotyledon cell wall and intracellular matrix are factors that limit iron bioavailability of the common bean (Phaseolus vulgaris). Food Funct. 7, 3193-3200. doi: 10.1039/C6FO00490C

Gowri, B., Platel, K., Prakash, J., and Srinivasan, K. (2001). Influence of amla fruits (Emblica officinalis) on the bio-availability of iron from staple cereals and pulses. Nutr. Res. 21, 1483-1492. doi: 10.1016/S0271-5317(01)00362-1

Gwala, S., Kyomugasho, C., Wainaina, I., Rousseau, S., Hendrickx, M., and Grauwet, T. (2020). Ageing, dehulling and cooking of Bambara groundnuts: consequences for mineral retention and in vitro bioaccessibility. Food Funct. 11, 2509-2521. doi: 10.1039/C9FO01731C

Hemalatha, S., Platel, K., and Srinivasan, K. (2007a). Influence of heat processing on the bioaccessibility of zinc and iron from cereals and pulses consumed in India. J. Trace Elem. Med. Biol. 21, 1-7. doi: 10.1016/j.jtemb.2006.10.002

Hemalatha, S., Platel, K., and Srinivasan, K. (2007b). Zinc and iron contents and their bioaccessibility in cereals and pulses consumed in India. Food Chem. 102, 1328-1336. doi: 10.1016/j.foodchem.2006.07.015

Hurrell, R., and Egli, I. (2010). Iron bioavailability and dietary reference values. Am. J. Clin. Nutr. 91, 1461-1467. doi: 10.3945/ajcn0.2010.28674F

ICMR-NIN (2020). Recommended Dietary Allowances and Estimated Average Requirements Nutrient Requirements for Indians. Hyderabad: Indian Council of Medical Research National Institute of Nutrition.

Jha, N., Krishnan, R., and Meera, M. (2015). Effect of different soaking conditions on inhibitory factors and bioaccessibility of iron and zinc in pearl millet. $J$. Cereal Sci. 66, 46-52. doi: 10.1016/j.jcs.2015.10.002

Kapsokefalou, M., and Miller, D. D. (1991). Effects of meat and selected food components on the valence of non-heme iron during in vitro digestion. J. Food Sci. 56, 352-355. doi: 10.1111/j.1365-2621.1991.tb05278.x

Khoja, K. K., Aslam, M. F., Sharp, P. A., and Latunde-Dada, G. O. (2021). In vitro bioaccessibility and bioavailability of iron from fenugreek, baobab and moringa. Food Chem. 335:127671. doi: 10.1016/j.foodchem.2020.127671

Kiers, J. L., Nout, R. M. J., and Rombouts, F. M. (2000). In vitro digestibility of processed and fermented soya bean, cowpea and maize. J. Sci. Food Agric. 80, 1325-1331. doi: 10.1002/1097-0010(200007)80:9<1325::AID-JSFA648>3.0.CO;2-K

Larsson, M., Minekus, M., and Havenaar, R. (1997). Estimation of the bioavailability of iron and phosphorus in cereals using a dynamic in vitro gastrointestinal model. J. Sci. Food Agric. 74, 99-106.

Lestienne, I., Besançon, P., Caporiccio, B., Lullien-Péllerin, V., and Tréche, S. (2005a). Iron and zinc in vitro availability in pearl millet flours (Pennisetum glaucum) with varying phytate, tannin, and fiber contents. J. Agric. Food Chem. 53, 3240-3247. doi: 10.1021/jf0480593 
Lestienne, I., Caporiccio, B., Besançon, P., Rochette, I., and Trèche, S. (2005b). Relative contribution of phytates, fibers, and tannins to low iron and zinc in vitro solubility in pearl millet (Pennisetum glaucum) flour and grain fractions. J. Agric. Food Chem. 53, 8342-8348. doi: 10.1021/jf050741p

Longvah, T., Anantan, I., Bhaskarachary, K., Venkaiah, K., and Longvah, T. (2017). Indian Food Composition Tables. Indian Council of Medical Research Hyderabad.

Luo, Y., Xie, W., and Cui, Q. (2010). Effects of phytases and dehulling treatments on in vitro iron and zinc bioavailability in faba bean (Vicia faba L.) flour and legume fractions. J. Food Sci. 75, 191-198. doi: 10.1111/j.1750-3841.2009.01490.x

Luo, Y.-W., Xie, W.-H., Jin, X.-X., Wang, Q., and Zai, X.-M. (2013). Effects of germination and cooking for enhanced in vitro iron, calcium and zinc bioaccessibility from faba bean, azuki bean and mung bean sprouts. CyTA-J. Food 11, 318-323. doi: 10.1080/19476337.2012.757756

Luten, J., Crews, H., Flynn, A., Van Dael, P., Kastenmayer, P., Hurrell, R., et al. (1996). Interlaboratory trial on the determination of the in vitro iron dialysability from food. J. Sci. Food Agric. 72, 415-424.

Mamiro, P., Mwanri, A., Mamiro, D., Nyagaya, M., and Ntwenya, J. (2016). In-vitro bioavailability of selected minerals in dry and green shelled beans. Afr. J. Agric. Res. 11, 730-737. doi: 10.5897/AJAR2012.883

Mamiro, P., Van, J., Mwikya, S., and Huyghebaert, A. (2001). In vitro extractability of calcium, iron, and zinc in finger millet and kidney beans during processing. J. Food Sci. 66, 1271-1275. doi: 10.1111/j.1365-2621.2001.tb15200.x

Mamiro, P. S., Kolsteren, P. W., van Camp, J. H., Roberfroid, D. A., Tatala, S., and Opsomer, A. S. (2004). Processed complementary food does not improve growth or hemoglobin status of rural Tanzanian infants from 6-12 months of age in Kilosa district, Tanzania. J. Nutr. 134, 1084-1090. doi: $10.1093 /$ jn/134.5.1084

Miller, D. D., Schricker, B. R., Rasmussen, R. R., and Van Campen, D. (1981). An in vitro method for estimation of iron availability from meals. Am. J. Clin. Nutr. 34, 2248-2256. doi: 10.1093/ajcn/34.10.2248

Minekus, M. (2015). “The TNO gastro-intestinal model (TIM)," in The Impact of Food Bioactives on Health, eds K. Verhoeckx, P. Cotter, I. López-Expósito, C. Kleiveland, T. Lea, A. Mackie, T. Requena, D. Swiatecka, and H. Wichers (Berlin: Springer), 37-46. doi: 10.1007/978-3-319-16104-4_5

Minekus, M., Alminger, M., Alvito, P., Ballance, S., Bohn, T., Bourlieu, C., et al. (2014). A standardised static in vitro digestion method suitable for food-an international consensus. Food. Funct. 5, 1113-1124. doi: 10.1039/C3FO60702J

Minekus, M., Marteau, P., Havenaar, R., and Huis in't Veld, J. H. H. (1995). A multicompartmental dynamic computer-controlled model simulating the stomach and small intestine. Altern. Lab. Anim. 23, 197-209. doi: 10.1177/026119299502300205

Muleya, M., Young, S. D., and Bailey, E. H. (2021). A stable isotope approach to accurately determine iron and zinc bioaccessibility in cereals and legumes based on a modified INFOGEST static in vitro digestion method. Food Res. Int. 139:109948. doi: 10.1016/j.foodres.2020.109948

Nair, K. M., and Iyengar, V. (2009). Iron content, bioavailability and factors affecting iron status of Indians. Indian J. Med. Res. 130, 634-645.

Pizarro, F., Olivares, M., Valenzuela, C., Brito, A., Weinborn, V., Flores, S., et al. (2016). The effect of proteins from animal source foods on heme iron bioavailability in humans. Food Chem. 196, 733-738. doi: 10.1016/j.foodchem.2015.10.012

Platel, K., and Srinivasan, K. (2016). Bioavailability of micronutrients from plant foods: an update. Crit. Rev. Food Sci. Nutr. 56, 1608-1619. doi: 10.1080/10408398.2013.781011

Pynaert, I., Armah, C., Fairweather-Tait, S., Kolsteren, P., Van Camp, J., and De Henauw, S. (2006). Iron solubility compared with in vitro digestion-Caco-2 cell culture method for the assessment of iron bioavailability in a processed and unprocessed complementary food for Tanzanian infants (6-12 months). Br. J. Nutr. 95, 721-726. doi: 10.1079/BJN20051722

Rodriguez-Ramiro, I., Dell'Aquila, C., Ward, J., Neal, A., Bruggraber, S., Shewry, P., et al. (2019). Estimation of the iron bioavailability in green vegetables using an in vitro digestion/Caco-2 cell model. Food Chem. 301:125292. doi: 10.1016/j.foodchem.2019.125292

Rousseau, S., Kyomugasho, C., Celus, M., Hendrickx, M. E., and Grauwet, T. (2020). Barriers impairing mineral bioaccessibility and bioavailability in plant-based foods and the perspectives for food processing. Crit. Rev. Food Sci. Nutr. 60, 826-843. doi: 10.1080/10408398.2018.15 52243

Sahuquillo, A., Barberá, R., and Farré, R. (2003). Bioaccessibility of calcium, iron and zinc from three legume samples. Nahrung 47, 438-441. doi: 10.1002/food.200390097

Sebastiá, V., Barberá, R., Farré, R., and Lagarda, M. J. (2001). Effects of legume processing on calcium, iron and zinc contents and dialysabilities. J. Sci. Food Agric. 81, 1180-1185. doi: 10.1002/jsfa.927

Sotelo, A., González-Osnaya, L., Sánchez-Chinchillas, A., and Trejo, A. (2010). Role of oxate, phytate, tannins and cooking on iron bioavailability from foods commonly consumed in Mexico. Int. J. Food Sci. Nutr. 61, 29-39. doi: 10.3109/09637480903213649

Tripathi, B., and Platel, K. (2011). Iron fortification of finger millet (Eleucine coracana) flour with EDTA and folic acid as co-fortificants. Food Chem. 126, 537-542. doi: 10.1016/j.foodchem.2010.11.039

Tuyizere, J. D., Okidi, L., Elolu, S., and Ongeng, D. (2021). In vitro bioavailabilitybased assessment of the contribution of wild fruits and vegetables to household dietary iron requirements among rural households in a developing country setting: the case of acholi subregion of Uganda. Food Sci. Nutr. 9, 625-638. doi: $10.1002 /$ fsn 3.1977

Valencia, U. S., Ann-Sofie, S., and Jenny, R. (1999). Processing of quinoa (Chenopodium quinoa, Willd): effects on in vitro iron availability and phytate hydrolysis. Int. J. Food Sci. Nutr. 50, 203-211. doi: 10.1080/096374899101247

WHO (2020). Who Guideline on Use of Ferritin Concentrations to Assess Iron Status in Individuals and Populations. WHO.

Yun, S., Habicht, J.-P., Miller, D. D., and Glahn, R. P. (2004). An in vitro digestion/Caco-2 cell culture system accurately predicts the effects of ascorbic acid and polyphenolic compounds on iron bioavailability in humans. J. Nutr. 134, 2717-2721. doi: 10.1093/jn/134.10.2717

Conflict of Interest: The authors declare that the research was conducted in the absence of any commercial or financial relationships that could be construed as a potential conflict of interest.

Publisher's Note: All claims expressed in this article are solely those of the authors and do not necessarily represent those of their affiliated organizations, or those of the publisher, the editors and the reviewers. Any product that may be evaluated in this article, or claim that may be made by its manufacturer, is not guaranteed or endorsed by the publisher.

Copyright (c) 2021 Sulaiman, Givens and Anitha. This is an open-access article distributed under the terms of the Creative Commons Attribution License (CC BY). The use, distribution or reproduction in other forums is permitted, provided the original author(s) and the copyright owner(s) are credited and that the original publication in this journal is cited, in accordance with accepted academic practice. No use, distribution or reproduction is permitted which does not comply with these terms. 